\title{
RADIATION EXPOSURE IN ACCESSORY PATHWAY ABLATION PROCEDURES IN CARDIAC ELECTROPHYSIOLOGY: A RETROSPECTIVE ANALYSIS
}

\author{
*M. Ali1,2, B. Banavalikar1, M.K. Ghadei'1, A. Kottayan', \\ D. Padmanabhan ${ }^{1}$, J. Shenthar ${ }^{1}$ \\ 1 - DEPARTMENT OF CARDIAC ELECTROPHYSIOLOGY, SRI JAYADEVA INSTITUTE OF CARDIOVASCULAR \\ SCIENCES AND RESEARCH, BANGALORE, INDIA \\ 2 - DEPARTMENT OF CARDIOLOGY, SHER-I-KASHMIR INSTITUTE OF MEDICAL SCIENCES, \\ SRINAGAR, KASHMIR, INDIA
}

Background. Radiofrequency catheter ablation (CA) has been the treatment of choice in patients with accessory pathway (AP)-mediated tachycardias. Most of these procedures are done under fluoroscopic guidance, leading to significant radiation exposure to the patient and the laboratory personnel. In this analysis, we have looked at the amount of radiation exposure in AP CA procedures performed without the support of a threedimensional electroanatomic mapping system. We have analyzed changes in exposure indices over the study period and the impact of change in fluoroscopy frame rate (FFR).

Objectives. The objectives of this study are to quantify radiation exposure in accessory pathway ablation procedures; to analyze the radiation exposure trend over time; and to evaluate the effect of fluoroscopy frame rate reduction on the radiation exposure indices in these procedures.

Methods. All the AP ablation procedures performed at our institute from January 2016 to December 2019 were retrospectively analyzed. The collected data were age, sex, location of APs based on successful site of ablation on fluoroscopy, procedure time, fluoroscopy time, and dose-area product (DAP). Effective dose (ED) was estimated from DAP. The data of procedures performed before January 2018 ("pre" group) were compared with those of the procedures performed after that date ("post" group). Pre-group procedures were performed at an FFR of 7.5 frames per second (fps), and post-group procedures - at an FFR of $3.75 \mathrm{fps}$.

Results. The total number of procedures included in the analysis was 635. The mean age of the patients was $39 \pm 14$ years, and 401 of them (63\%) were males. The most common location of the APs was left lateral (38\%). Procedure time and radiation indices showed a significant decrease over the study period $(p<0.001)$. Post group procedures had significantly shorter procedure time and lower radiation exposure than pre group procedures.

Conclusions. A decrease in the FFR was associated with a significant reduction in radiation exposure in AP ablation procedures

KEYWORDS: accessory pathway; catheter ablation; dose-area product; fluoroscopy time; radiation exposure.

\section{Introduction}

The ablation of accessory pathways (AP) using radiofrequency energy was first introduced by Borggrefe and colleagues in 1987 when they ablated a right-sided accessory pathway for the first time in humans using radiofrequency energy [1]. Since then, radiofrequency ablation has been the treatment of choice in patients with accessory pathwaymediated tachycardias [2,3]. Although radiofrequency ablation for AP-mediated tachycardias is a highly efficacious and safe treatment

*Corresponding author: Dr. Muzaffar Ali, Department of Cardiology, SKIMS, Srinagar, Kashmir, India. Email: dralimuzaffar@gmail.com option, some of the adverse effects of this procedure are not because of the procedure itself but because of the ionizing radiation used to visualize the catheters during the procedure. Ionizing radiation exposure affects the patient and the laboratory personnel because of the fluoroscopic imaging used during cardiac electrophysiology (EP) procedures.

The ionizing radiation exposure can cause long-term hazardous effects, including malignancy, cataract formation, thyroid dysfunction, dermatitis, germline mutations, etc. This is due to double-strand breaks induced in the DNA backbone brought about by the free radicals 
generated due to the exposure of ionizing radiations [4].

The hazard of radiation exposure increases with the higher radiation dose, which in turn increases with the longer duration of EP procedure for the patient and increase in the number of EP procedures for the laboratory staff. Thus, it is essential to evaluate the benefit of the intended EP procedure over the risk of expected exposure to ionizing radiation and minimize the radiation exposure levels to minimum achievable levels for both the patients and the laboratory staff to have an overall beneficial outcome of the EP procedure [4].

One way to decrease radiation exposure in cardiac electrophysiology procedures is to use a lower fluoroscopy frame rate. We have previously reported of the impact of fluoroscopy frame rate reduction in complex catheter ablation procedures performed under a threedimensional electroanatomic mapping system [5]. In this study, we analyzed radiation exposure indices in our laboratory's AP ablation procedures. We have also analyzed the impact of fluoroscopy frame rate reduction on radiation exposure indices during these procedures.

The objectives of this study are: to quantify radiation exposure in accessory pathway ablation procedures; to analyze the radiation exposure trend over time; and to evaluate the effect of fluoroscopy frame rate reduction on the radiation exposure indices in these procedures.

\section{Methods}

A retrospective analysis of accessory pathway ablation procedures carried out in a tertiary care referral institute in Southern India was performed. The data were collected from January 2016 to December 2019. The data available were age, sex, location of successful ablation, fluoroscopy time, and dose area product (DAP).

Procedures without such data were exclu ded. Patients with multiple accessory pathways were also excluded from the analysis. The procedure time for catheter ablation procedures was defined as the time from the administration of a local anesthetic agent to removing catheters from the patient's body. Our institute has an ongoing cardiac electrophysiology fellowship program, and the fellows assist in all the catheter ablation procedures performed in our laboratory. Four physicians performed the catheter ablation procedures with an experience of $21,11,6$, and 4 years in interventional electrophysiology. All the catheter ablation procedures were performed without threedimensional electroanatomic mapping. The institute has an active EP fellowship program running since 2009 , and the fellows assist in all the procedures performed in the laboratory. The laboratory is equipped with the Philips Allura Xper FD 10 system (Philips Healthcare, the Netherlands), and all the procedures were performed using the same system.

The fluoroscopy frame rate used in the laboratory was $7.5 \mathrm{fps}$ before February 2018. From the beginning of February 2018, fluoroscopy at $3.75 \mathrm{fps}$ have been used. The location of the accessory pathways was determined by the location of successful ablation in the left anterior oblique (LAO) projection, as shown in Figure 1.

The Effective Dose (ED, $\mathrm{mSv}$ ) was estimated from DAP provided by the X-ray system by multiplying DAP with the following conversion factors depending on the age of the patient: $5-10$ years of age: $1.0 ; 10-15$ years of age: 0.6 ; 15-20 years of age: 0.4 ; adult females: 0.28 and adult males: 0.2. Lifetime attributable risk (LAR) of cancer incidence and mortality was derived from the ED by multiplying it with $0.0001 / \mathrm{mSv}$ (the standardized BEIR VII conversion factor) [5].

The data were summarized using standard descriptive statistics and presented as the arithmetic means with standard deviation (SD) or median with interquartile range, as appropriate. Nonparametric statistical tests like the Kruskal-Wallis test and the Mann-Whitney $U$ test were used to analyze the procedure time and radiation exposure parameters over the study period and the effect of fluoroscopy fra-

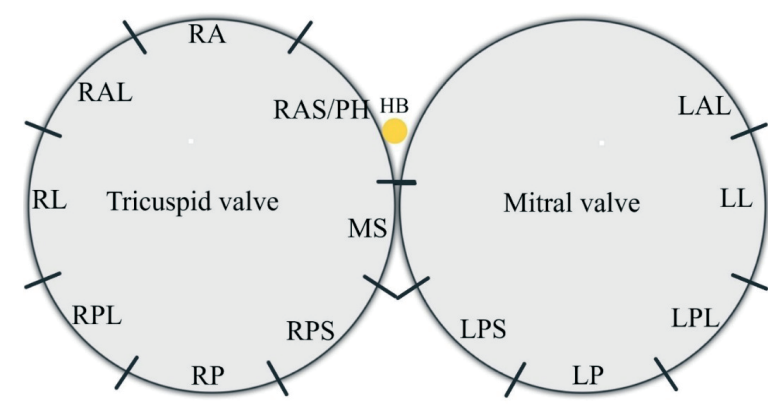

Fig. 1. Location of accessory pathways as seen on a left anterior oblique (LAO) projection.

$H B$ : His Bundle; LAL: left anterolateral; LL: left lateral; LPL: left posterolateral; LP: left posterior; LPS: left posteroseptal; RPS: right posteroseptal; RP: right posterior; $R P L$ : right posterolateral; $R L$ : right lateral; $R A L$ : right anterolateral; $R A$ : right anterior; RAS/PH: right anteroseptal/para-Hisian; MS: midseptal. 
me rate over various parameters, respectively. The level of significance was fixed at $p<0.05$.

Institutional ethical committee approval was not applied for this retrospective analysis. Informed consent was obtained from all patients before the procedures, which included the clause that their data could be used for scientific purposes in the future.

Statistical Package for the Social Sciences (SPSS), version 20, was used to perform statistical analysis.

\section{Results}

Six hundred and thirty-five pathway ablation procedures were included in the analysis. The mean age of the patients was $39 \pm 14$ years. The mean age of male patients $(n=401 ; 63 \%$ of the total) was $39 \pm 13$ years, and female patients $(n=234 ; 37 \%$ of the total) were $40 \pm 14$ years.

The location of the accessory pathways and the associated procedure time and radiation indices are presented in Table 1. The number of the pathways ablated from the left side was

$372(58.6 \%)$, and that from the right were 263 $(41.4 \%)$. The most common location of the ablated pathways was left lateral, which was $38.4 \%$ of all the pathways, and the second most common location was right posteroseptal, which was $27.2 \%$ of all the pathways. The least common location of accessory pathways was mid septal $(0.3 \%)$ followed by right anterolateral $(0.5 \%)$ and right anterior $(0.5 \%)$ locations.

Trends in various indices over the study period are shown in Table 2. 15\% (96) of all the procedures were performed in 2016. In the years 2017, 2018, and 2019 the proportion of the procedures performed was $23 \%$ (149), $31 \%$ (196), and 31\% (194), respectively.

Trends in the indices before (pre group) and after (post group) the change in fluoroscopy frame rate are shown in Table 3. $41 \%$ of the procedures $(n=260)$ were performed under fluoroscopy frame rate of $7.5 \mathrm{fps}$, and $59 \%$ of the procedures $(n=375)$ were performed under fluoroscopy frame rate of $3.75 \mathrm{fps}$.

\section{Discussion}

Table 1. Procedure time and radiation indices based on the successful location of ablation on fluoroscopy in left anterior oblique projection

\begin{tabular}{|l|c|c|c|c|c|c|}
\hline Pathways & No. (\%) & $\begin{array}{c}\text { Procedure } \\
\text { Time (min) }\end{array}$ & $\begin{array}{c}\text { Fluoroscopy } \\
\text { Time }(\mathrm{min})\end{array}$ & $\begin{array}{c}\text { DAP } \\
\left(\mathrm{cGy} / \mathrm{cm}^{2}\right)\end{array}$ & $\begin{array}{c}\text { ED } \\
(\mathrm{mSv})\end{array}$ & $\begin{array}{c}\text { LAR, } \\
\%\end{array}$ \\
\hline LAL & $18(2.8)$ & $55(45-98)$ & $10(8-14)$ & $538(313-706)$ & $1.1(0.8-1.5)$ & $0.01(0.008-0.02)$ \\
\hline LL & $244(38.4)$ & $55(45-75)$ & $11(8-17)$ & $796(480-1343)$ & $1.8(1.1-3.1)$ & $0.02(0.01-0.03)$ \\
\hline LPL & $34(5.4)$ & $55(44-81)$ & $12(7-17)$ & $787(483-1884)$ & $1.9(1.0-4.1)$ & $0.02(0.01-0.04)$ \\
\hline LP & $22(3.5)$ & $58(48-66)$ & $13(7-19)$ & $1014(456-1570)$ & $2.3(1.1-3.5)$ & $0.02(0.01-0.03)$ \\
\hline LPS & $54(8.5)$ & $80(55-106)$ & $20(10-29)$ & $1637(795-2384)$ & $3.6(1.8-5.3)$ & $0.04(0.02-0.05)$ \\
\hline RPS & $173(27.2)$ & $60(43-90)$ & $13(8-19)$ & $988(465-1609)$ & $2.1(1.1-3.6)$ & $0.02(0.01-0.04)$ \\
\hline RP & $12(1.9)$ & $60(36-94)$ & $15(7-26)$ & $1372(411-3420)$ & $2.7(0.8-8.2)$ & $0.03(0.01-0.08)$ \\
\hline RPL & $24(3.8)$ & $69(55-100)$ & $19(11-26)$ & $1220(738-2448)$ & $3.5(1.8-5.5)$ & $0.04(0.02-0.06)$ \\
\hline RL & $27(4.3)$ & $90(70-120)$ & $27(15-43)$ & $1534(848-2529)$ & $3.6(1.7-7.5)$ & $0.04(0.02-0.08)$ \\
\hline RAL & $3(0.5)$ & $105(45-105)$ & $17(11-17)$ & $701(288-701)$ & $2.8(0.6-2.8)$ & $0.03(0.005-0.3)$ \\
\hline RA & $3(0.5)$ & $65(60-65)$ & $21(18-21)$ & $1596(723-1596)$ & $4.4(1.5-4.4)$ & $0.04(0.01-0.4)$ \\
\hline AS/PH & $19(3.0)$ & $65(46-80)$ & $15(7-18)$ & $555(441-862)$ & $1.2(0.9-2.3)$ & $0.01(0.01-0.02)$ \\
\hline MS & $2(0.3)$ & $100(45-100)$ & $21(7-21)$ & $1549(377-1549)$ & $3.1(0.8-3.1)$ & $0.01(0.007-0.01$ \\
\hline Total & $635(100.0)$ & $60(45-90)$ & $13(8-19)$ & $889(488-1660)$ & $2.1(1.1-3.7)$ & $0.02(0.01-0.04)$ \\
\hline
\end{tabular}

Notes: LAL: left anterolateral; LL: left lateral; LPL: left posterolateral; LP: left posterior; LPS: left posteroseptal; RPS: right posteroseptal; RP: right posterior; RPL: right posterolateral; RL: right lateral; RAL: right anterolateral; RA: right anterior; RAS/PH: right anteroseptal/para-Hisian; HB: His bundle; MS: midseptal.

Table 2. Change in procedure time and radiation indices over the study period

\begin{tabular}{|l|c|c|c|c|c|c|}
\hline Year & Number & $\begin{array}{c}\text { Procedure } \\
\text { time (mins) }\end{array}$ & $\begin{array}{c}\text { Fluoroscopy } \\
\text { time (mins) }\end{array}$ & DAP (cGy/cm $\left.{ }^{2}\right)$ & ED (mSv) & LAR, \% \\
\hline 2016 & 96 & $75(51-94)$ & $19(11-25)$ & $1254(751-2527)$ & $3.1(1.6-5.8)$ & $0.03(0.02-0.06)$ \\
\hline 2017 & 149 & $75(60-110)$ & $17(12-30)$ & $1604(789-2713)$ & $3.5(1.8-5.7)$ & $0.04(0.02-0.06)$ \\
\hline 2018 & 196 & $60(45-80)$ & $12(9-17)$ & $798(445-1284)$ & $1.8(1.0-3.1)$ & $0.02(0.01-0.03)$ \\
\hline 2019 & 194 & $50(40-65)$ & $9(6-12)$ & $596(335-1079)$ & $1.4(0.8-2.4)$ & $0.01(0.008-0.02)$ \\
\hline & p-value & $<0.001$ & $<0.001$ & $<0.001$ & $<0.001$ & $<0.001$ \\
\hline
\end{tabular}


Table 3. Impact of fluoroscopy frame rate change on procedure time and radiation indices. Pre-group: procedures performed at $7.5 \mathrm{fps}$; post-group: procedures performed at $3.75 \mathrm{fps}$

\begin{tabular}{|l|c|c|c|c|c|c|}
\hline & Number & $\begin{array}{c}\text { Procedure time } \\
\text { (mins) }\end{array}$ & $\begin{array}{c}\text { Fluoroscopy } \\
\text { time (mins) }\end{array}$ & $\begin{array}{c}\text { DAP } \\
\left(\mathrm{cGy} / \mathrm{cm}^{2}\right)\end{array}$ & $\begin{array}{c}\text { ED } \\
(\mathrm{mSv})\end{array}$ & $\begin{array}{c}\text { LAR, } \\
\%\end{array}$ \\
\hline Pre & 260 & $75(55-104)$ & $18(12-27)$ & $1432(780-2564)$ & $3.2(1.8-5.7)$ & $0.03(0.02-0.06)$ \\
\hline Post & 375 & $55(40-75)$ & $10(7-15)$ & $698(392-1176)$ & $1.6(0.9-2.7)$ & $0.02(0.01-0.03)$ \\
\hline & p-value & $<0.001$ & $<0.001$ & $<0.001$ & $<0.001$ & $<0.001$ \\
\hline
\end{tabular}

The main findings of our study are:

a. There was a significant increase in the number of catheter ablation procedures performed in our laboratory over the study period.

b. The procedure time and the radiation indices (fluoroscopy time, DAP, ED, and LAR) significantly decreased over the study period ( $p<0.001$ for all the parameters).

c. The trend of a significant decrease in procedure time and radiation exposure continued when the data were divided into two groups based on the fluoroscopy frame rate $(p<0.001$ for all the parameters).

The radiation indices reported in different studies of catheter ablation procedures are presented in Table 4. The radiation indices reported are comparable to that of the published data.

Injury caused by exposure to ionizing radiation can be classified into two groups: a) the deterministic effects and b) the stochastic effects. Deterministic effects are dose-dependent (e.g., cataracts and skin injuries). A threshold radiation dose is a radiation dose below which the deterministic effects are not produced.

On the other hand, even a tiny radiation dose involves an increased risk of stochastic effects (e.g., cancer), and the chances of suffering that effect are directly proportional to the radiation dose.

As no radiation dose is safe, the policy of maintaining radiation exposure level is dependent on the "as low as reasonably achievable" (ALARA) principle. [4]

Some of the factors that influence the extent of ionizing radiation exposure in a cardiac EP laboratory are:

1) Operator dependent: a) experience of the operators, b) training of operators with simulators, c) radiation awareness of the staff, d) C-arm projection used during the procedure, e) fluoroscopy frame rate, f) cine duration, g) cine substitution by stored fluoroscopy, h) fluoroscopy use during catheter removal from the body, i) collimation of the X-ray system, j) pelvic radiation, $k$ ) written report of the patient's radiation exposure during the procedure.

Table 4. Reported radiation exposure in catheter ablation of supraventricular tachycardias (SVT). Adapted from [9]

\begin{tabular}{|c|c|c|c|c|c|}
\hline Study & Type of study & $\begin{array}{c}\text { Number of } \\
\text { patients }\end{array}$ & $\begin{array}{l}\text { Fluoroscopy } \\
\text { time (mins) }\end{array}$ & $\mathrm{DAP}\left(\mathrm{cGy} / \mathrm{cm}^{2}\right)$ & $\begin{array}{c}\text { Effective Dose } \\
(\mathrm{mSv})\end{array}$ \\
\hline $\begin{array}{l}\text { Smith IR et al. } \\
\text { [10] }\end{array}$ & Retrospective & $\begin{array}{l}\text { AVNRT } 270 \\
\text { AVRT } 135\end{array}$ & \begin{tabular}{|c|}
$2.1(1.3-4.5)$ \\
$23.8(13.4-45.3)$
\end{tabular} & $\begin{array}{c}260(170-610) \\
2690(1600-5410)\end{array}$ & - \\
\hline $\begin{array}{l}\text { Rogers DP } \\
\text { et al. [7] }\end{array}$ & Observational & $\begin{array}{l}\text { Pre DRM } 147 \\
\text { (AVNRT/AVRT) } \\
\text { Post DRM } 257 \\
\text { (AVNRT/AVRT) } \\
\end{array}$ & - & $\begin{array}{l}2040 \pm 2690 \\
800 \pm 1030\end{array}$ & $\begin{array}{l}3.3 \\
1.24\end{array}$ \\
\hline $\begin{array}{l}\text { Heidbuchel H } \\
\text { et al. [4] }\end{array}$ & $\begin{array}{l}\text { EHRA practical } \\
\text { guide }\end{array}$ & - & - & - & $4.4(1.6-25)$ \\
\hline $\begin{array}{l}\text { Casella M } \\
\text { et al. [6] }\end{array}$ & $\begin{array}{l}\text { Multicentre } \\
\text { randomized }\end{array}$ & $\begin{array}{l}\text { Pre DRM } 128 \\
\text { Post DRM } 134\end{array}$ & $\begin{array}{c}14.32(9.08- \\
22.43) \\
0(0-0.2) \\
\end{array}$ & $\begin{array}{c}2036(54-5297) \\
278(80-791)\end{array}$ & $\begin{array}{c}8.87(3.67-22.01) \\
0(0-0.08)\end{array}$ \\
\hline $\begin{array}{l}\text { See J et al. } \\
\text { [11] }\end{array}$ & Observational & $\begin{array}{l}\text { Pre DRM AVRT } 55 \\
\text { Post DRM AVRT } 44\end{array}$ & $\begin{array}{l}49.0 \pm 36.3 \\
14.1 \pm 13.4 \\
\end{array}$ & $\begin{array}{c}3292 \pm 3282.7 \\
654.4 \pm 645.5\end{array}$ & - \\
\hline $\begin{array}{l}\text { Casella M } \\
\text { et al. [9] }\end{array}$ & Retrospective & 979 (SVT) & $13(6-21)$ & 1721(727-3884) & $4.1(1.8-9.1)$ \\
\hline Our data & Retrospective & $\begin{array}{l}\text { Pre } 260 \\
\text { Post } 375\end{array}$ & $\begin{array}{c}18(12-27) \\
10(7-15)\end{array}$ & $\begin{array}{c}1432(780-2564) \\
698(392-1176)\end{array}$ & $\begin{array}{l}3.2(1.8-5.7) \\
1.6(0.9-2.7)\end{array}$ \\
\hline
\end{tabular}


2) Patient dependent: a) body habitus of the patient, b) arrhythmic lesion to be ablated.

3) Technology dependent: a) X-ray system, b) combination with computed tomography $(\mathrm{CT}), \mathrm{c})$ three-dimensional electroanatomic mapping systems, d) shielding of the laboratory personnel. [4]

The factors that lead to decreased radiation exposure in the cardiac EP laboratory are:

1) Operator dependent: a) expert operators, b) operators who have been trained with simulators, c) radiation aware staff, d) predominant usage of right anterior oblique $\mathrm{C}$-arm projection than an anteroposterior of left anterior oblique projection, e) low frame rate of fluoroscopy ( $<6 \mathrm{fps})$, f) short cine duration, g) frequent cine substitution by stored fluoroscopy, h) catheter withdrawal from the body without using fluoroscopy, i) optimized and adapted collimation, $\mathrm{j}$ ) avoidance of pelvic radiation, k) a written report of the patient's radiation exposure that includes air kerma or dose area product received during the procedure.

2) Patient dependent: lean body habitus of the patients, supraventricular tachycardia ablation than atrial fibrillation ablation or ventricular tachycardia ablation,

3) Technology dependent: cardiac EP tuned $X$-ray system which has been adequately maintained and inspected for quality control, no preprocedural or rotational computed tomography, the predominant use of threedimensional electroanatomic mapping systems, proper shielding which includes above and below the table or cabin shielding [4].

One of the most efficient ways to decrease radiation exposure during the ablation of accessory pathways is to perform these procedures with the help of three-dimensional electroanatomic mapping, which has been shown to decrease radiation exposure in such procedures significantly.

No-Party trial was the first multicentre, prospective, randomized trial that compared conventional fluoroscopy-guided catheter ablation procedures with procedures performed using the three-dimensional electroanatomic mapping system in the patients undergoing EP study for supraventricular tachycardias, $36 \%$ of whom were AP ablation procedures [6]. In this trial, three-dimensional electroanatomic mapping significantly reduced fluoroscopy time and ED ( 0 seconds and $0 \mathrm{mSv}$ ) when compared to the procedures performed under fluoroscopic guidance ( 859 seconds and $8.87 \mathrm{mSv})(p<0.00001)$.
But the use of three-dimensional electroanatomic mapping systems is restricted due to various logistic reasons (availability, lack of expertise); we need to find alternative ways to decrease radiation exposure during catheter ablation procedures [4].

Rogers AJ et al. conducted a study to evaluate the effect of radiation dose-reduction maneuver on the radiation exposure in EP laboratory. Atrioventricular nodal reentrant and AP-mediated tachycardia was $64 \%$ of catheter ablation procedures. They showed that with the simple maneuver of removing a secondary radiation grid to improve image quality and reducing the fluoroscopy pulse rate from 12.5 to 6.25 pulses/second, a radiation dose reduced from 20.4 to $8.0 \mathrm{Gycm}^{2}$. Additionally, the risk of radiation-related fatal malignancy was reduced by 63 due to the implementation of the maneuver. This study showed the importance of selecting electrophysiology laboratory parameters in reducing radiation exposure during catheter ablation procedures [7].

Voskoboinik A et al. conducted a prospective study to analyze the trends in radiation exposure during AF ablation at a single center over 12 years. A significant and progressive decrease in the fluoroscopy time and ED was observed over time. The significant decrease in the patient and operator radiation exposure was attributed to increased operator experience, higher annual case volume, technology evolution over time, and recent use of contact force-sensing catheters. [8]

More recently, Casella $\mathrm{M}$ et al. have reported fluoroscopy data from their retrospective analysis of various EP and device implantation procedures at a large volume laboratory over 7 years. Fluoroscopy time, DAP, and ED showed a statistically significant reduction trend for all EP procedures. Based on the obtained results, it was proposed that a combination of operator awareness about the fluoroscopy-associated risk and technological advancement can be used for optimizing the use of fluoroscopy in EP procedures [9].

One of the significant limitations of this study, other than being a retrospective analysis, is that one can argue that a significant decrease in the procedure duration can solely explain the changes in the radiation exposure in the procedure time, which is also reflected in the decrease in the fluoroscopy time. If there is a significant decrease in the procedure time, the radiation exposure will automatically decrease. 
Some of the other limitations of this study are that data regarding some of the other factors that influence radiation exposure during procedures (e.g., body mass index of the patients, cine exposure duration during the procedures) performed under fluoroscopy was not available. This study is based on retrospective data collected from a single center, and the results cannot be generalized to other centers. As already alluded to, radiation exposure also depends on the individual expertise of operators, but data regarding the radiation exposure of individual operators was not available.

We propose that in our study, the decrease in the radiation indices is not solely because of the reduction in fluoroscopy frame rate but because of other factors, too, one being a more than $200 \%$ increase in the yearly number of ablation procedures performed over the study period. Any modern electrophysiology laboratory will face the same scenario.

\section{Conclusions}

A reduction in the fluoroscopy frame rate and improvement in the electrophysiology laboratory workflow leads to a significant decrease in the radiation exposure during catheter ablation procedures of accessory pathway-mediated tachycardias.

\section{Conflict of interest}

The authors declare no conflict of interest. Authors' contributions

Muzaffar Ali: formal analysis, writing original draft, investigation, formal analysis. Bharatraj Banavalikar: writing - reviewing and editing, investigation, formal analysis. Milan Kumar Ghadei: formal analysis, writing - original draft, investigation, formal analysis. Anju Kottayan: formal analysis, writing - original draft, investigation, formal analysis. Deepak Padmanabhan: writing - reviewing and editing, investigation, formal analysis. Jayaprakash Shenthar: conceptualization, methodology, writing - reviewing and editing

\title{
ІОНІЗУЮЧЕ ОПРОМІНЕННЯ ПРИ РАДІОЧАСТОТНІЙ АБЛЯЩІї ДОДАТКОВИХ ШЛЯХІВ ПРОВЕДЕННЯ У ЕЛЕКТРОФІЗІОЛОГІЇ СЕРЦЯ: РЕТРОСПЕКТИВНИЙ АНАЛІЗ
}

\author{
*M. Ali'1,2, B. Banavalikar1, M.K. Ghadei', A. Kottayan', D. Padmanabhan', J. Shenthar ${ }^{1}$ \\ 1 - DEPARTMENT OF CARDIAC ELECTROPHYSIOLOGY, SRI JAYADEVA INSTITUTE OF CARDIOVASCULAR SCIENCES \\ AND RESEARCH, BANGALORE, INDIA \\ 2 - DEPARTMENT OF CARDIOLOGY, SHER-I-KASHMIR INSTITUTE OF MEDICAL SCIENCES, SRINAGAR,
} KASHMIR, INDIA

Вступ. Радіочастотна катетерна абляція (КА) метод вибору лікування у пацієнтів з тахікардією, додатковими шляхами (ДШ). Більшість таких процедур проводиться під флюороскопічним наглядом, що призводить до значного опромінення пацієнта та персоналу лабораторії. у цьому аналізі ми розглянули радіаційне опромінення в процедурах КАДШ, виконаних без підтримки тривимірної системи електроанатомічного відображення. Ми проаналізували зміни показників експозиції за період дослідження та вплив зміни частоти кадрів флюороскопії (FFR).

Мета. Метою цього дослідження $\epsilon$ (1) кількісна оцінка радіаційного опромінення в процедурах абляції додаткових шляхів, (2) аналіз тенденції радіаційного опромінення з часом та (3) оцінка впливу зменшення частоти кадрів флюороскопії на показники радіаційного опромінення під час чієї процедури.

Методи. Ми ретроспективно проаналізували всі процедури абляції ДШ, проведені в нашому інституті з січня 2016 року по грудень 2019 року. Зібрані дані: вік, стать, місце розташування ДШ на основі успішного місця абляції на флюороскопії, час процедури, час флюороскопії та індекс доза опромінення відносно площі (DAP). Ефективну дозу (ЕД) оцінювали за DАР. Дані процедур, проведених до січня 2018 р. (група "До"), порівнювались із даними процедур, проведених після чієі дати (група "Після"). Прочедури групи "До" виконувались із частотою FFR 7,5 кадрів в секунду (fps), а процедури групи "Після"з частотою FFR 3,75 fps.

Результати. Загальна кількість процедур, включених до аналізу, становила 635. Середній вік

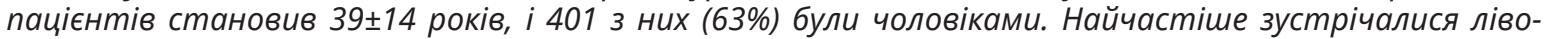
латеральні ДШ (38\%). Показники тривалості процедури та опромінення зменшилися протягом періоду дослідження (p<0,001). Процедури групи "Після" мали значно коротший час проведення КА та менший радіаційний вплив, ніж процедури групи "До".

Висновки. Зменшення FFR було пов'язане зі значним зменшенням радіаційного опромінення в прочедурах аблячії ДШ.

КЛЮчОВІ СЛОВА: додаткові шляхи проведення; катетерна абляція; дозування опромінення; час флюороскопії; радіаційне опромінення. 


\section{Information about the authors}

Muzaffar Ali MD, DM: Department of Cardiac Electrophysiology, Sri Jayadeva Institute of Cardiovascular

Sciences and Research, Bangalore, India.

ORCID 0000-0002-3489-5864, email: dralmuzaffar@gmail.com

Bharatraj Banavalikar MD, DM: Department of Cardiac Electrophysiology, Sri Jayadeva Institute of Cardiovascular Sciences and Research, Bangalore, India.

ORCID 0000-0003-1116-3967, email: bharatrajnb@gmail.com

Milan Kumar Ghadei MD, DM: Department of Cardiac Electrophysiology, Sri Jayadeva Institute of Cardiovascular Sciences and Research, Bangalore, India.dr.milan80@gmail.com

Anju Kottayan BSc: Department of Cardiac Electrophysiology, Sri Jayadeva Institute of Cardiovascular Sciences and Research, Bangalore, India. anjukottayan@gmail.com

Deepak Padmanabhan MD, DM: Department of Cardiac Electrophysiology, Sri Jayadeva Institute of Cardiovascular Sciences and Research, Bangalore, India.

ORCID 0000-0002-9127-9275, email: deepak.padmanabhan@gmail.com

Jayaprakash Shenthar MD, DM, FACC, FRCP (Lond): Department of Cardiac Electrophysiology, Sri Jayadeva Institute of Cardiovascular Sciences and Research, Bangalore, India.

ORCID 0000-0003-4509-7515, email: jpsbhat@gmail.com

\section{References}

1. Borggrefe M, Budde T, Podczeck A, Breithardt G. High frequency alternating current ablation of an accessory pathway in humans. 10:7. DOI: 10.1016/ s0735-1097(87)80200-0

2. Page RL, Jogler JA, Caldwell MA. 2015 ACC/AHA/ HRS guideline for the management of adult patients with supraventricular tachycardia. Heart Rhythm. 2015;13(4):86. DOI: 10.1016/j.hrthm.2015.09.019

3. Katritsis DG, Arbelo E, Arribas F. The Task Force for the management of patients with supraventricular tachycardia of the European Society of Cardiology (ESC). Eur Heart J. 41(2020):655-720. DOI: 10.1093/ eurheartj/ehz467

4. Heidbuchel H, Wittkampf FHM, Vano E, Ernst S, Schilling R, Picano $E$, et al. Practical ways to reduce radiation dose for patients and staff during device implantations and electrophysiological procedures. EP Eur. 2014 Jul 1;16(7):946-64. DOI: 10.1093/ europace/eut409

5. Ali M, Padmanabhan D, Kanjwal K, Ghadei MK, Kottayan A, Banavalikar B, et al. Effect of fluoroscopy frame rate on radiation exposure and in-hospital outcomes in three-dimensional electroanatomic mapping guided procedures. J Arrhythmia. 2021;37:97-102. DOI: 10.1002/joa3.12496

6. Casella M, Dello Russo A, Pelargonio G, Del Greco M, Zingarini G, Piacenti M, et al. near zero fluoroscopic exposure during catheter ablation of supraventricular arrhythmias: the no-party multicentre randomized trial. Europace. 2016 Oct;18(10): 1565-72. DOI: 10.1093/europace/euv344
7. Rogers DPS, England F, Lozhkin K, Lowe MD, Lambiase PD, Chow AWC. Improving safety in the electrophysiology laboratory using a simple radiation dose reduction strategy: a study of 1007 radiofrequency ablation procedures. Heart. 2011 Mar 1;97(5):366-70. DOI: 10.1136/hrt.2010.204222

8. Voskoboinik A, Kalman ES, Savicky Y, Sparks PB, Morton JB, Lee $G$, et al. Reduction in radiation dose for atrial fibrillation ablation over time: A 12-year single-center experience of 2344 patients. Heart Rhythm. 2017 Jun;14(6):810-6. DOI: 10.1016/j. hrthm.2017.02.014

9. Casella M, Dello Russo A, Russo E, Catto V, Pizzamiglio F, Zucchetti M, et al. X-Ray Exposure in Cardiac Electrophysiology: A Retrospective Analysis in 8150 Patients Over 7 Years of Activity in a Modern, Large-Volume Laboratory. J Am Heart Assoc. 2018 Jun 5;7(11). DOI: 10.1161/JAHA.117.008233

10. Smith IR, Rivers JT, Hayes J, Stafford W, Codd C. Reassessment of Radiation Risks from Electrophysiology Procedures Compared to Coronary Angiography. Heart Lung Circ. 2009 Jun;18(3):191-9. DOI: 10.1016/j.hlc.2008.10.006

11. See J, Amora J, Lee S, Lim P, Teo W, Tan B, et al. Non-fluoroscopic navigation systems for radiofrequency catheter ablation for supraventricular tachycardia reduce ionising radiation exposure. Singapore Med J. 2016 Jul;57(07):390-5. DOI: 10.11622/smedj.2016017

Received 23 May 2021; revised 20 Jun 2021; accepted 22 Jun 2021.

This is open access article distributed under the Creative Commons Attribution License, which permits unrestricted use, distribution, and reproduction in any medium, provided the original work is properly cited. 